Pak. j. sci. ind. res. Ser. A: phys. sci. 2020 63A(3) 176-187

\title{
Geospatial Mapping, Environmetrics and Indexing Approach for a Tropical River Sediment in Southern Nigeria
}

\author{
Osikemekha Anthony Anania*, John Ovie Olomukorob and Alex Ajeh Enuneku ${ }^{c}$ \\ ${ }^{a}$ Laboratory of Ecotoxicology and Forensic Biology, Department of Biological Science, Faculty of Science, \\ Edo University Iyamho, PMB 04, Auchi, Edo State, Nigeria \\ ${ }^{b}$ Department of Animal and Environmental Biology, Faculty of Life Science, University of Benin, \\ Benin City, PMB 1154, Nigeria \\ ${ }^{\mathrm{c}}$ Department of Environmental Management and Toxicology, Faculty of Life Science
}

(received December 4, 2018; revised August 31, 2019; accepted September 3, 2019)

\begin{abstract}
The objectives of this study are to assess the trace and heavy metals pollution in the sediments of Ossiomo river, using geospatial mapping, environmetrics and ecological risk indices. The results from the descriptive statistics showed that there was significant difference $(\mathrm{P}<0.05)$ of the mean values of Fe, $\mathrm{Mn}, \mathrm{Cu}, \mathrm{Cr}, \mathrm{Cd}, \mathrm{Pb}, \mathrm{Ni}$ and $\mathrm{V}$. A posterior analysis using Duncan multiple regression analysis showed that stations 2 and 3 were significantly different from stations 1 and 4 . While, there was no significant difference $(\mathrm{P}>0.05)$ in the mean values of $\mathrm{Zn}$ across the stations. The results of the relationship of the metals revealed a negative correlation between $\mathrm{Fe}$ and $\mathrm{Mn}$ with the other metals correspondingly. The results of the Kriging interpolation indicated a strong bull eye colour for stations 2 and 3 (6.42), while stations 1 and 4 were minimal (1.4). The results of the geospatial mapping indicated Fe, $\mathrm{Zn}$ and $\mathrm{Mn}$ to be the most dominant metals across the stations. The results of the PCA (principal component analysis) yielded 16 variables under 9 components with Eigenvalues $>1$ in components $1-6$ and these variables explained $99.99 \%$ of the total variance in the sediment. The results of the degree of suitability and sphericity of the PCA revealed a high significant difference at $\mathrm{P}<0.001$. The results of the potential ecological risk index values were very high in station 2 (824.30) and 3 (802.11) correspondingly. That of index of geo-accumulation was generally low $(<2)$. The findings from this study generally revealed the source apportionment of the trace and heavy metals to come from anthropogenic influences such as farming; fertilizers. Sustainable agriculture is highly recommended in order to reduce the impacts of anthropogenic activities, deterioration of the ecosystem and possible death of the life forms in this watercourse.
\end{abstract}

Keywords: tukey pairwise, kriging, interpolation, geospatial; envirometrics, ossiomo

\section{Introduction}

River water has been an undeniable natural resource responsible for the major hub of human interests. In Nigeria, river water is a dependable source for many human activities. Man's quest for water of good quality is in a dire state. The upset of the river benthic sediment by the activities of man such as dredging and de-silting, can cause re-suspension of trace and heavy metals in the ecosystem. Natural activities such as flooding, erosion, volcanic eruption and earthquakes, animal activities such as bioturbation also raise serious concern for the safety of the water we consume.

The sandy, clayey, silt and other particles of the soil that settle down in the benthic region of a body of any aquatic ecosystem is termed sediment. Many authors

*Author for correspondence;

E-mail: osikemekha.anani@edouniversity.edu.ng and cybert2004@gmail.com like (Anani and Olomukoro, 2017; Bhardwaj et al., 2017; Olomukoro, 2017; Al-Taani et al., 2015; Bai et al., 2011; Chen et al., 2007; Adamo et al., 2005) have worked on the uptake of metals directly from the sediments, by benthic organisms, which in turn enhance the potential of some metals entering into the food chain and thus results in severe ecological and health risk conditions (Enuneku et al., 2018; Anani and olomukoro, 2018; 2017).

Recent studies on the impact of trace and heavy metals in river sediment in Nigeria have been established by (Anani and Olomukoro, 2017; Odoemelam et al., 2013; Opaluwa et al., 2012; Ugwu et al., 2012; Addo et al., 2011; Dougherty et al., 2000) revealing high, low and fluctuating trace and heavy metal contents within different river stretches.

Apart from superficial water, sediment is known as a pivotal sink hole of pollutants in any river bed. To 
quantify the source ecological risk (s), several mathematical models or indices are used to assess the chemical contaminants or natural pollution caused by human activities or lithogenic point sources (Anani and Olomukoro, 2017 and 2018; Balasim, 2013). Several ecological risk models recommended are: the Potential Ecological Risk Index (PERI), Hakanson (1980) and Martin and Meybeck (1979), index of geo-accumulation (I-geo) and the Enrichment factors (Reimann and Caritat 2005; Boszke et al. 2004; Duce et al., 1975; Muller, 1969) Pollution Index (PI) and Nemerow Integrated Pollution Index (NIPI) by Caeiro et al. (2005) and heavy metal evaluation index (HEI) by Bhuiyan et al. (2010). The geospatial mapping, environmetrics and indexing approach for assessing the trend of chemical in a river ecosystem have been established by many authors (Bhardwaj et al., 2017; Reza and Singh, 2010; Nair et al., 2010; Yalcin et al., 2010; Prasad and Kumari, 2008). These methods could be used to quantify the main problem for the decline of water fitness and source apportionment of extremely polluted points within a given river ecosystem.

Toxic metals in very high quantity have been shown to cause toxicological effects in living things (water life forms, land invertebrates and humans along the food chain (Anani and Olomukoro, 2018; Anani, 2017) the natural environment (Talarico et al., 2014; Nummelin et al., 2007; Essien et al., 2006).

The objectives of this research work are: (1) to assess the trace and heavy metals contamination in the bottom sediments using geospatial mapping method (2) to evaluate the main point sources of trace and heavy metals in Ossiomo river using environmetrics approach Principal Component Analysis (PCA) and (3) to ascertain the most unfavourably polluted point along the stretch of the river using potential ecological risk indices and index of geo accumulation.

\section{Materials and Methods}

Description of the study area. About $5.1 \mathrm{~km}$ stretch of Ossiomo river (Ologbo axis), Benin city situated in the south west of Nigeria, was assessed. The following geographical locations; Latitude $6^{\circ} 031$ ' $\mathrm{N}$ - Longitude $5^{\circ} 40^{\prime} 3^{\prime} \mathrm{E}$ (Fig. 1) were mapped out and assessed.

Four sampling stations in the river were selected to reflect the upstream and the downstream status of the river based on the possible amount of agricultural and other anthropogenic pollution it received. One unique feature of this river, is that it divides or forms the boundary of two states (Edo and Delta) and contributing to the economic hub of both states through all the natural resources therein with the following ecological factors and geographical locations (Table 1 and Fig. 1).

Geology. The surface geology of the study area (Ologbo; Ossiomo river) took its source from the Ishan plateau of the Edo state and the geological plain formation (Benin formation) that span the south-central boundary of Edo state and beyond and empties its course on the Benin river and there in the Atlantic ocean. Three geologic formations are recognizable from the distinct attributes of depositional circles of sediments since the early Cretaceous in the area. They are upper Benin sands, middle Agbada of inter-bedded sands/marine shale's and lower Akata made up of massive and regressive marine shale's and clays deposits.

Climatic conditions and human activities. The type of weather of Ologbo and its neighborhoods is not steady. It is somewhat like that of the Benin city. A tempo of precipitation occurs in combination with the movement of the south-west rainy season breeze across the Atlantic ocean and the programming of this movement varies from year to year (Afangideh et al., 2008). Two separate yearly seasons related to this region: the rainy season, which starts in early March and culminate in late November, and the dry season which starts from November and culminate in March. Rainfall for 2015, ranged from $160.7-708.5 \mathrm{~mm}$ with the lowest recorded in the month of May $(158.4 \mathrm{~mm})$ and the highest recorded in the month of September (708.5 $\mathrm{mm})$. The average precipitation value was $(434.6 \mathrm{~mm})$.

The principal plants here include aquatic macrophytes and terrestrial plants; Pandanus candelabrum (Screw pine), Elaeis guineensis (palm tree), Azolla africana (Mosquito Fern or Water Velvet), Nymphaea lotus (red and blue water lily), Cyperus alopecuroides (Umbrella palm), Salvinia nymphellula (water moss), Echinochloa pyramidalis (Antelope grass or Barnyard grass or Cockspur grass) and Pistia stratiotes (water cabbage, Water lettuce, Nile cabbage, or shellflower). A lot of human activities within and proximate to this river include crude oil exploration and processing, discharging of cassava effluent, transportation, laundering, bathing and swimming, logging, saw-milling, fishing, boating, watercraft maintenance.

Sampling methods and trace metal extraction. Samples of sediment were collected within March 2015 - August 
Table 1. Sampling locations of Ossiomo river, Edo state Benin city

\begin{tabular}{lllll}
\hline \hline Stations & Location & Latitude (N) & Longitude (E) & Anthropogenic activities and source points. \\
\hline 1 & Ologbo & $6^{\circ} 02^{\prime} .890^{\prime \prime}$ & $5^{\circ} 39^{\prime} .599^{\prime \prime}$ & $\begin{array}{l}\text { A reference zone free from anthropogenic activities. } \\
\text { Closed to a timber factory and deck of boats and where human } \\
\text { activities are very high; and crude oil exploration and processing. }\end{array}$ \\
3 & Ologbo & $6^{\circ} 01^{\prime} .759^{\prime \prime}$ & $5^{\circ} 38^{\prime} .344^{\prime \prime}$ & $\begin{array}{l}\text { Closed to a local distiller, palm oil farm (PRESCO), cassava farm } \\
\text { and sawmills. }\end{array}$ \\
4 & Ologbo & $6^{\circ} 0^{\prime} .859^{\prime \prime}$ & $5^{\circ} 36^{\prime} .870^{\prime \prime}$ & Closed to a large cassava farm and sawmill. \\
\hline \hline
\end{tabular}

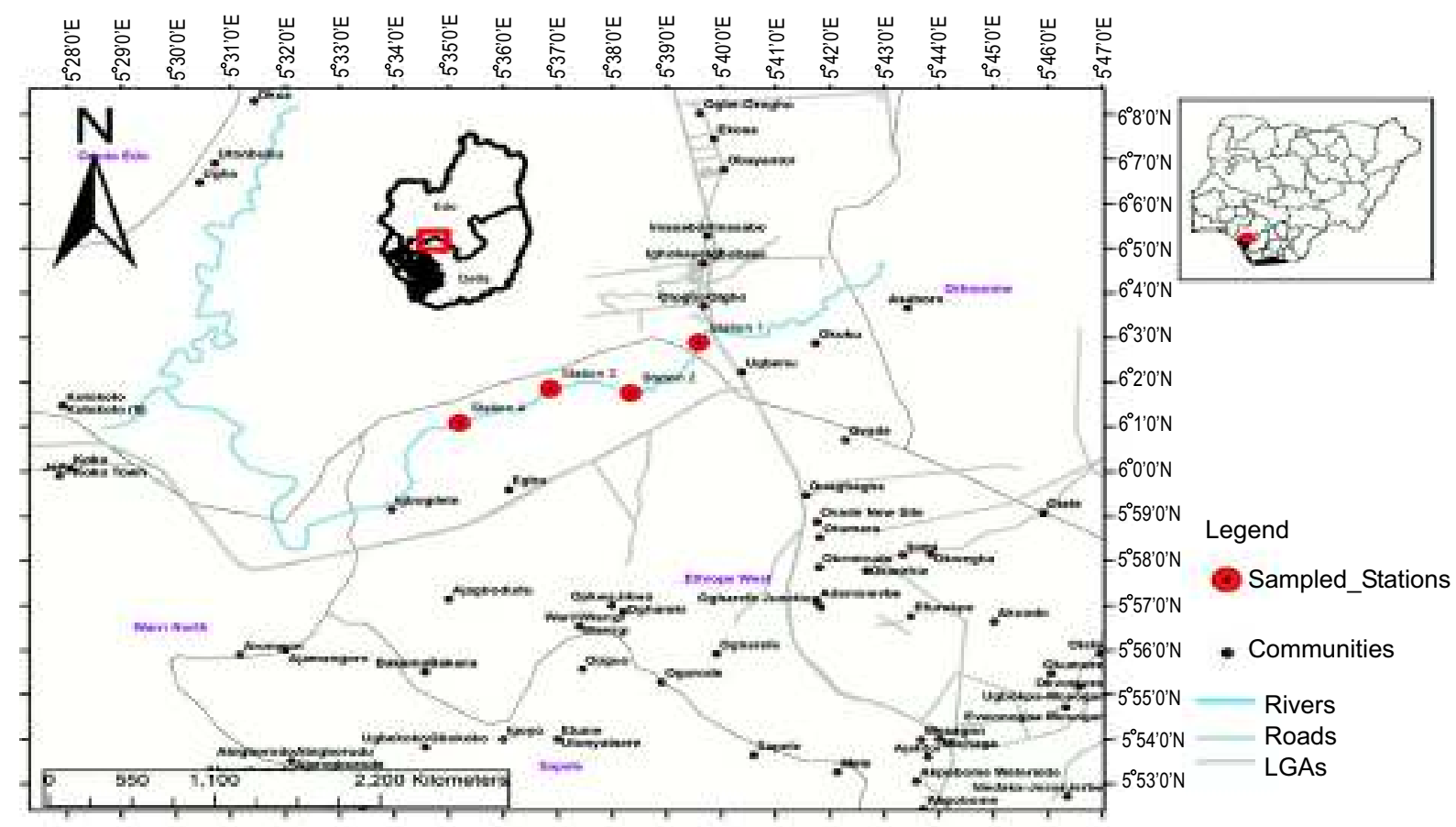

Fig. 1. Map of the study area and sampling stations showing sampled points of Ossiomo river, Edo state, Nigeria.

2016 with an Eckman grab from a depth of $150 \mathrm{~cm}$ from four stations in triplicate and pulled together as a composite sample in quality black polyethylene bags in accordance with standard procedures as described by APHA (2005).

The samples collected were taken to a research laboratory for further analysis. They were allowed to air-dry at room temperature, and were further dried in an oven at a temperature of $105^{\circ} \mathrm{C}$ and then were crumpled to a fine texture in a ceramic mortar, and thereafter sieved mechanically using a $0.5 \mathrm{~mm}$ mesh sieve. The trace and heavy metals, namely iron, manganese, zinc, copper, chromium, cadmium, lead, nickel, and vanadium in $\mathrm{g} / \mathrm{Kg}$, were analysed according to methods adopted from APHA (1998), Radojevic and Bashkin (1999) using an Atomic absorption spectrophotometer (Solar 969 Unicam Series model).

Data analysis. Comparisons between the station were done in order to test for significant differences in the chemical contents using one way parametric analysis of variance (ANOVA) set at $\mathrm{P}<0.05$. Where there was a significant difference, a posterior test was done set at $\mathrm{P}<0.01$ with Duncan multiple regression. T-test, KrustalWallis test for medians and the Tukey pair wise test were used to test for significant difference between stations and to source the relationship amongst the trace and heavy metals. 
Spatial interpolation method/geospatial mapping. The kriging interpolation was employed using the method of Tao (1995), Wang et al. (2003). The Variogram method by Oliver and Webster (1990) was used to forecast the values gotten and to estimate the spatial distribution of the trace and heavy metals. The source identification method by Tepanosyan et al. (2017) using ArcMap 10.1 was employed in this study.

Environmetrics approach. Principal component analysis (PCA) was used to deduce the theoretical source apportionment of the trace and heavy metals in this present study because, it is a useful environmental tool to better understand the relationships among the computed variables and for X-raying groups that are commonly connected in the interior of a computed data body supporting in the proof of sources of different contaminants (Bhardwaj et al., 2017).

The modified Kaiser-Meyer-Olkin (KMO) and Barlett's tests of sphericity (BTS) methods by Nair et al. (2010) and Bhardwaj et al. (2017) were employed to decide the suitability of using the PCA. The results gotten from this study were analysed using the statistical package, SPSS version 20.0 (SPSS, USA).

Ecological risk indexing approach. This research work implemented two ecological pollution indices which are:

Potential Ecological Risk Index (PERI) as by Hakanson (1980), Martin and Meybeck (1979) and Index of geoaccumulation (I-geo) as proposed by Muller, (1969) which was described by Boszke et al. (2004).

\section{Results and Discussion}

Evaluation of the spatial interpolation. Table 2 and 3 show the results of the characteristics of the trace and heavy metals in Ossiomo river and their test of relationship amongst them respectively. The results from the descriptive statistics showed that there was a significant difference $(\mathrm{P}<0.05)$ of the mean values $\mathrm{Fe}$, $\mathrm{Mn}, \mathrm{Cu}, \mathrm{Cr}, \mathrm{Cd}, \mathrm{Pb}, \mathrm{Ni}$ and $\mathrm{V}$. A posterior analysis using Duncan multiple regression analysis showed that stations 2 and 3 were significantly different from stations 1 and 4 , while there was no significant difference $(\mathrm{P}>0.05)$ in the mean values of $\mathrm{Zn}$.

It was observed that all the examined trace and heavy metals exceeded the standard limits (Table 2) as set by WHO and Federal Environmental Protection Agency (2003). Similar findings were also reported by Anani

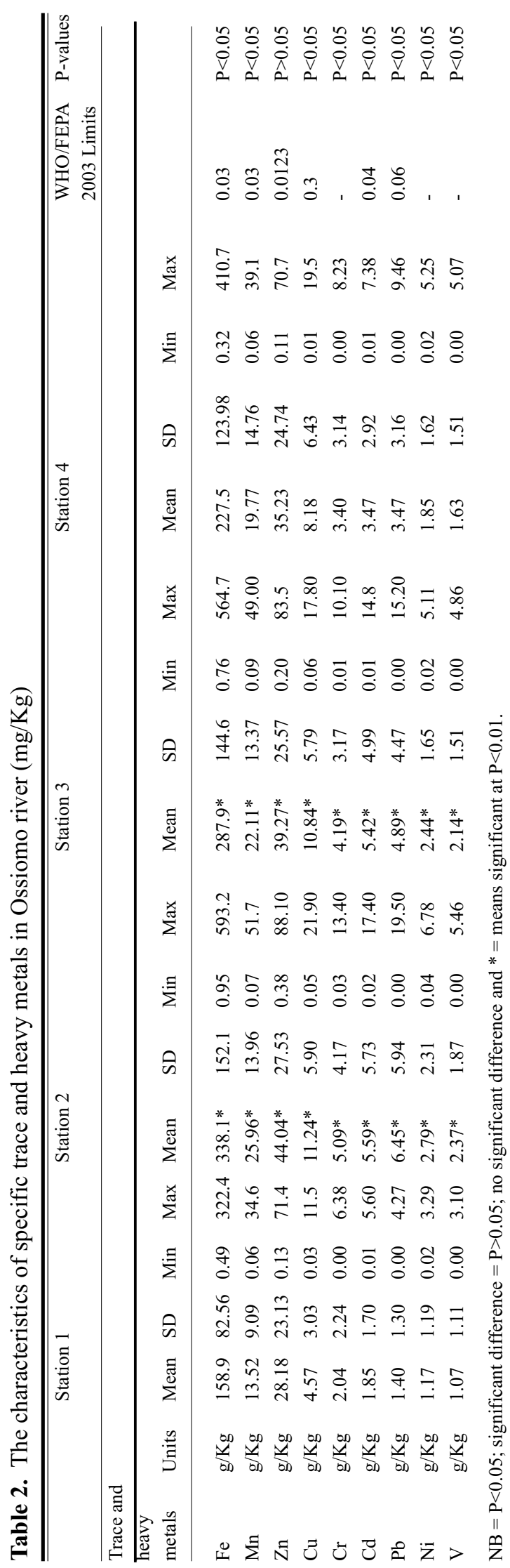


Table 3. Test of relationship amongst trace and heavy metals in Ossiomo river using a Tukey pairwise test.

\begin{tabular}{llllllllll}
\hline \hline Parameters in $\mathrm{g} / \mathrm{Kg}$ & $\mathrm{Fe}$ & $\mathrm{Zn}$ & $\mathrm{Mn}$ & $\mathrm{Cu}$ & $\mathrm{Pb}$ & $\mathrm{Cr}$ & $\mathrm{Cd}$ & $\mathrm{Ni}$ & $\mathrm{V}$ \\
\hline $\mathrm{Fe}$ & & $\mathbf{1 E - 0 5}$ & $\mathbf{1 E - 0 5}$ & $\mathbf{1 E - 0 5}$ & $\mathbf{1 E - 0 5}$ & $\mathbf{1 E - 0 5}$ & $\mathbf{1 E - 0 5}$ & $\mathbf{1 E - 0 5}$ & $\mathbf{1 E - 0 5}$ \\
$\mathrm{Zn}$ & 40.86 & & $\mathbf{6 E - 0 1}$ & $\mathbf{9 E - 0 1}$ & $\mathbf{5 E - 0 1}$ & $\mathbf{6 E - 0 1}$ & $\mathbf{6 E - 0 1}$ & $\mathbf{4 E - 0 1}$ & $\mathbf{4 E - 0 1}$ \\
$\mathrm{Mn}$ & 38.09 & & & $\mathbf{2 E - 0 2}$ & $\mathbf{2 E - 0 3}$ & $\mathbf{3 E - 0 3}$ & $\mathbf{3 E - 0 3}$ & $\mathbf{1 E - 0 3}$ & $\mathbf{8 E - 0 4}$ \\
$\mathrm{Cu}$ & 42.83 & $2 \mathrm{E}+00$ & $5 \mathrm{E}+00$ & & 1 & 1 & 1 & 1 & 1 \\
$\mathrm{~Pb}$ & 43.72 & 2.86 & 5.63 & 0.89 & & 1 & 1 & 1 & 1 \\
$\mathrm{Cr}$ & 43.62 & 2.76 & 5.53 & 0.79 & 0.10 & & 1 & 1 & 1 \\
$\mathrm{Cd}$ & 43.64 & 2.78 & 5.55 & 0.82 & 0.08 & $\mathbf{0 . 0 2}$ & & 1 & 1 \\
$\mathrm{Ni}$ & 44.01 & 3.15 & 5.92 & 1.19 & 0.29 & 0.39 & 0.37 & & 1 \\
$\mathrm{~V}$ & 44.06 & 3.19 & 5.97 & 1.23 & 0.34 & 0.44 & 0.42 & & $\mathbf{0 . 0 5}$ \\
\hline \hline
\end{tabular}

$\mathrm{NB}=$ Bolded values are less than the P-value of 0.05 are considered significant and negatively correlated. Ignore the negative sign (-). While others greater than 0.05 are not considered significant and are positively correlated. There is a significant difference between the Krustal-Wallis tests for sample medians, at $\mathrm{P}<0.05\left[\mathrm{H}\left(\mathrm{Chi}^{2}\right)=26.9\right.$ and $\mathrm{Hc}($ tie corrected $)=26.9$ ]. Therefore $\mathrm{P}($ same $)=3.09 \mathrm{E}-52$.

(2017), Anani and Olumukoro (2017 and 2018) in the same watercourse. The reason for this distinct increase of the concerned environmental parameters might be as a reason of the intense anthropogenic activities therein. A further analysis using one way ANOVA Tukey pair wise test revealed that there was a negative correlation between $\mathrm{Fe}$ with $\mathrm{Zn}, \mathrm{Mn}, \mathrm{Cu}, \mathrm{Pb}, \mathrm{Cr}, \mathrm{Cd}$, $\mathrm{Ni}$ and $\mathrm{V}$. More so, a negative correlation exists between $\mathrm{Mn}$ with $\mathrm{Pb}, \mathrm{Cr}, \mathrm{Cd}, \mathrm{Ni}$ and $\mathrm{V}$. The values were considered to be less than 0.05 after a statistical computation and were considered significant (Table 3). A negative correlation between $\mathrm{Fe}$ and the other metals can be as a result of its abundance in Nigeria sediment Anani and Olumukoro (2017). Also, Mn negative correlation with the other metals might be as a result of its strong oxidation variability and redox potentials. There was also a significant difference $(\mathrm{P}<0.05)$ between the Krustal-Wallis tests for sample medians; $\left[\mathrm{H}\left(\mathrm{Chi}^{2}\right)=26.9\right.$ and $\mathrm{Hc}($ tie corrected $\left.)=26.9\right]$. Therefore $\mathrm{P}($ same $)=3.09 \mathrm{E}-52$ (Table 3$)$.

Figure 2 shows the geospatial distribution of different trace and heavy metals $(\mathrm{Fe}, \mathrm{Mn}, \mathrm{Zn}, \mathrm{Cu}, \mathrm{Cr}, \mathrm{Cd}, \mathrm{Pb}$, and $\mathrm{Ni}$ ) in the study area. The kriging interpolation map shows the concentration and abundance of the trace and heavy metals across the studied stretch. The results of the Kriging interpolation indicated a strong bull eye colour value (6.42) in stations 2 and 3. The differing levels of metals as depicted by different colours of the interpolated values on the map are likely the consequence of intense anthropogenic activities such as farming, sourced (Fig. 3), in comparison with the reference station (station 1).

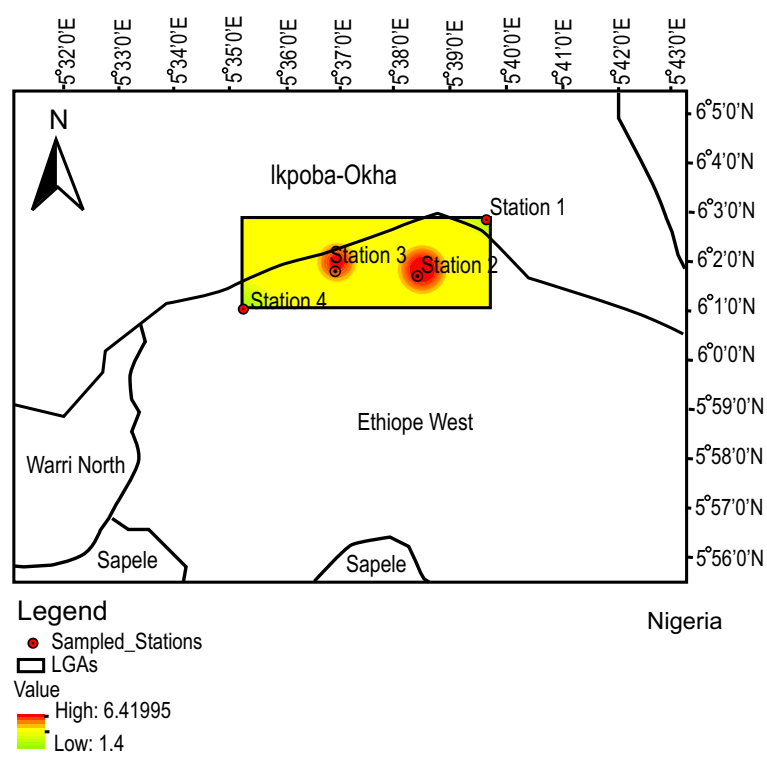

Fig. 2. Geospatial map of Ossiomo river showing Kriging interpolation of the sediment.

By inference, the findings of this study are similar with the works of (Anani and Olomukoro, 2018 and 2017; Aktar et al., 2010; Sundaray, 2009; Prasad et al., 2006), The geospatial analysis of these sites using the bull'seyes commonly associated with inverse distance to a power interpolation ITRC; Interstate Technology and Regulatory Council (2016), indicated stations 2 and 3 as very high with value of 6.42 , while stations 1 and 2 were considered as very low with a value of 1.4 . The importance of this statement is that values that are closer to one another in space or time will be more alike than 
values that are far away from one another (Webster and Oliver, 2007). According to ITRC (2016), if this were not true, there would be no rational basis for interpolating between sampling locations.

Krivoruchko (2011), proposed that spatial or temporal interpolation methods ideally produce predictions based with the following characteristics; predictions are based on measurements from nearby locations or time periods. Predictions have associated measurements of doubt, and a model is chosen to minimize this doubt to the extent practicable. Predictions can be converted to a probability of exceeding prescribed limit values. And predictions create smooth grids and contour maps without gaps. These affirmations, generally fit into the findings of this study.

Figure 3 shows the geospatial statistical map (bar graph) of the distribution of trace and heavy metals in Ossiomo River. The results of the geospatial mapping indicated $\mathrm{Fe}, \mathrm{Zn}$ and $\mathrm{Mn}$ to be the most dominant metals across the stations. The characterization of the general spatial distribution forms of trace and heavy metals with GISbased mapping indicated that stations 2 and 3 were highly polluted with their ranks; $\mathrm{Fe}>\mathrm{Mn}>\mathrm{Zn}>\mathrm{Cu}$ $>\mathrm{Cr}>\mathrm{Cd}>\mathrm{Pb}>\mathrm{Ni}>\mathrm{V}$.

Environmetrics evaluation. The principal component analysis (PCA) in Table 4 shows the proportion of variance by the different components extracted and the factor loadings of the different variables within the data set. The data sets yielded 16 variables under 9 components with Eigenvalues $>1$ in components 1- 6 and these variables explained $99.99 \%$ of the total variance in the sediment. The contributions were as follows - component 1, 2, 3, 4, 5 and 6 accounted for the variance proportion as: $98.9,0.89,0.13,0.04,0.02$ and $0.01 \%$ respectively, while components $7-9$ had eigen values $<1$ and these variables explained $1.87 \%$ of the total variance in the sediment. The contributions were as follows - component 7,8 and 9 accounted for: $0.97,0.89$ and $0.01 \%$ respectively. However, the Eigenvalues for PC7 and PC8 are approximately equal to 1 technically, thus accounting for $1.86 \%$ of the data set. The parameters of importance in each various components in terms of excellent or poor loadings were: (1) Fe (0.98) (2) Zn (0.43) and Mn (0.86) (3) Zn (0.78) (4) $\mathrm{Cu}(0.31), \mathrm{Cr}(0.61)$ and $\mathrm{Cd}(0.64)$ (5) $\mathrm{Ni}(0.44)$ and $\mathrm{V}(0.39)(6) \mathrm{Cu}(0.41), \mathrm{Ni}(0.54)$ and $\mathrm{V}(0.52)(7) \mathrm{Pb}$ (0.61) (8) $\mathrm{Pb}$ (0.71) (9) $\mathrm{Cr}$ (0.39) and V (0.73). Eight principal components (PC1, PC2, PC3, PC4, PC5, PC6, PC7 and PC8) having Eigen values $>1$ or $=1$ were gotten after the application of the PCA on the sediment parameters showing an aggregate variance of $101.85 \%$ (Fig. 4). In accordance with Grimm and Yarnold (2000), loadings $>0.71$ are typically regarded as excellent, and
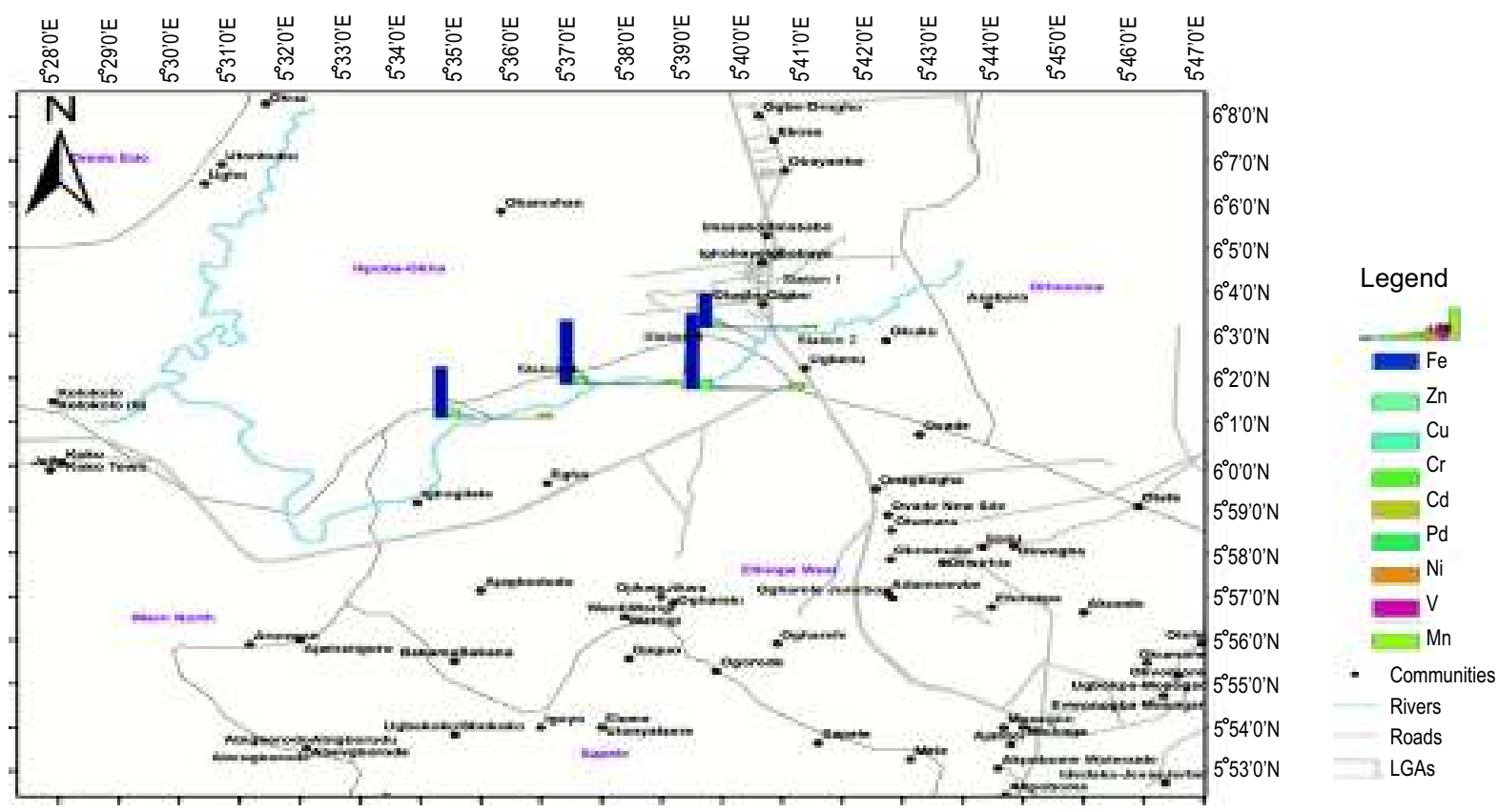

Fig. 3. Geospatial statistical map showing the distribution of trace and heavy metals in Ossiomo river 
Table 4. Principal component analysis loadings of trace and heavy metals in Ossiomo river.

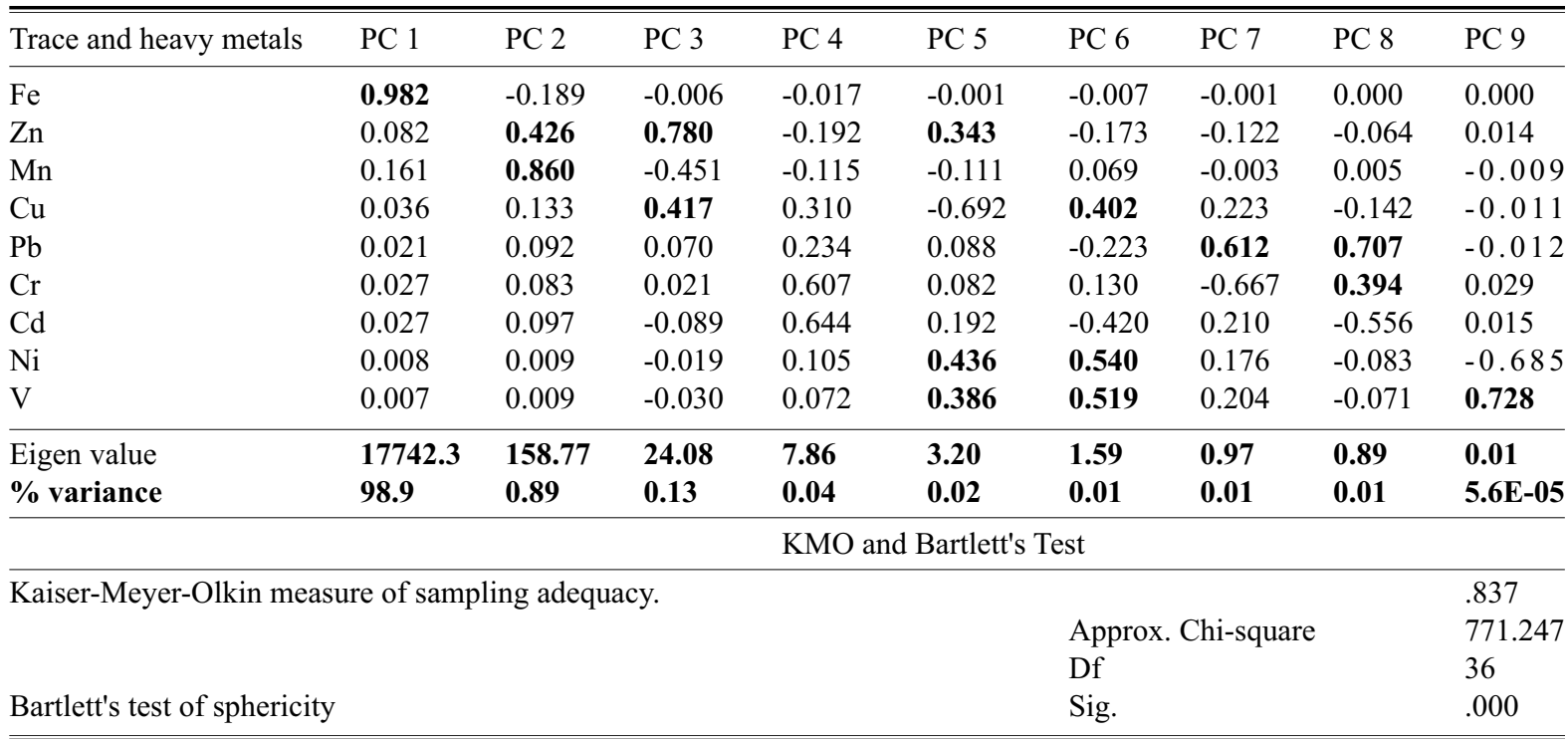

loadings $<0.32$ very poor. However, Nair et al. (2010) stated that the constituent with the maximum Eigen value is taken to be the most important and suitable concerns in the course of PCA. Loadings values of greater than 0.75 , in the middle of $0.75-0.5$ and $0.5-0.3$ are categorised as strong, moderate and weak respectively, founded on their entire values. It is interesting to note that the factor loadings in this current study were within the descriptions of Nair et al. (2010) and Grimm and Yarnold (2000) and were considered significant.

The poor loading for $\mathrm{Cu}, \mathrm{V}$ and $\mathrm{Cr}$ in $\mathrm{PC} 4, \mathrm{PC} 5$ and PC8 show that they exist at the point of pollution for

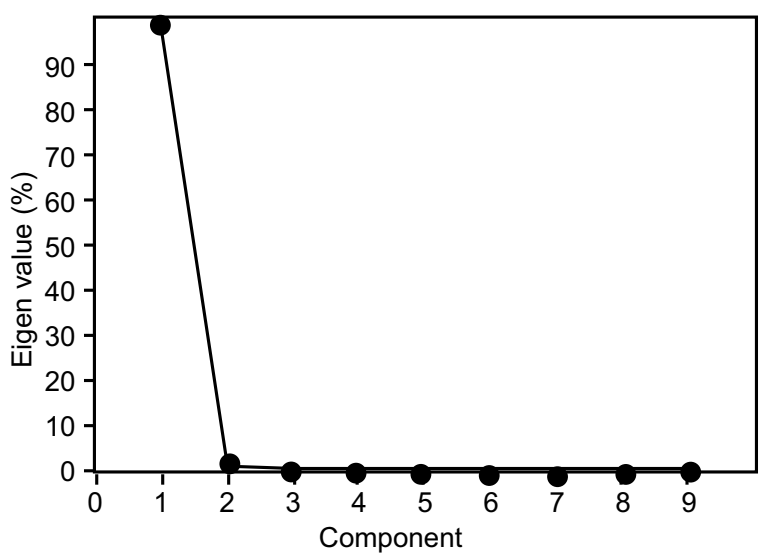

Fig. 4. Screen plot for the Eigen values indicating eight components. both the PCA. Demonstrating that they are main pollutants in Ossiomo river. This is in consonance with the findings on the descriptive statistics, Kriging interpolation and Tukey pairwise test analysis. The afore mentioned assertions are further demonstrated in Fig. 5. On this ground, this evaluates the descriptive statistics, Kriging interpolation and Tukey pairwise test that these nine trace and heavy metals might be grouped collectively for their mutual source and governing features (Bhardwaj et al., 2017).

Moreover, apart from the above poor loading trace and heavy metals, $\mathrm{Ni}$ and $\mathrm{Pb}$ were also clustered together indicating their source importance in the ecosystem.

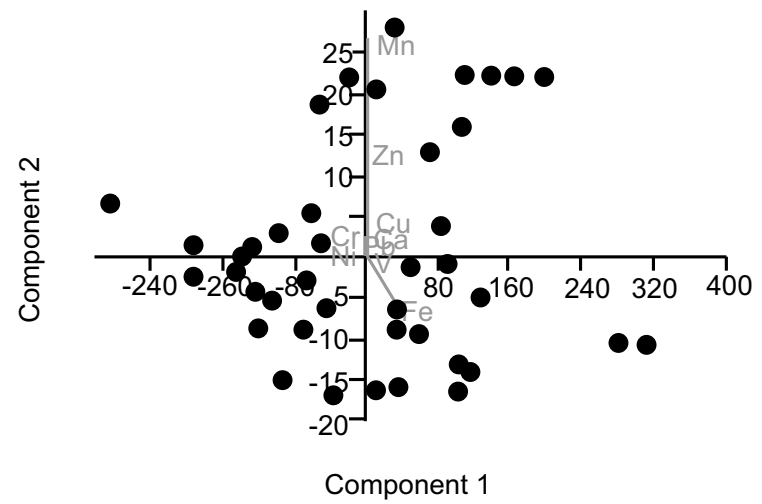

Fig. 5. Scatter plot for the components in rotated space 
Although their loading factors were extremely fair (Table 4 and Fig. 5). This clearly indicates that the source apportionment were from anthropogenic influences such as farming and has contributed negatively to the sediment pollution with deference to the premeditated trace and heavy metals which is in line with related works of (Reza and Singh, 2010; He et al., 2004; Abbasi et al., 1998; Trocine et al., 1993).

In this current study, the results of the KMO value obtained was 0.837 , which is an excellent degree of assessing the competence according to Bhardwaj et al. (2017). The BTS generated a very important value of $\mathrm{P}<0.001$, demonstrating that the relationship medium was not an individuality medium, and important associations are in existence with other variables (Bhardwaj et al., 2017). According to Bhardwaj et al. (2017), KMO and BTS (Table 3), confirm the correctness of the sediment data for the PCA extracted in this study.

Ecological risk indexing, evaluation. Pollution ecological risk index (PERI). Table 5 shows the results of the PERI of $\mathrm{Zn}, \mathrm{Cu}, \mathrm{Cr}, \mathrm{Cd}, \mathrm{Pb}$ and $\mathrm{Ni}$ in the four sampling stations with their comprehensive recommended rating. The findings in this study indicated that the average PERI values ranged from 0.22 to 606.01 $\mathrm{g} / \mathrm{Kg}$. From the risk interpretations, this indicated the metals in the four sampling stations all have very strong ecological risk level with the highest comprehensive PERI values of 824.30 and $802.11 \mathrm{~g} / \mathrm{Kg}$ at station 2 and 3 respectively. The main donator of the potential ecological RIs came from Cd (Table 5 and Fig. 6), this reveals its high toxic reaction influence as linked to other elements (Manoj and Padhy, 2014). Similar finding by Yisa et al. (2012) and Wei et al. (2010) Turekian and Wedepohl (1961), also demonstrated the higher role of $\mathrm{Cd}$ in triggering environmental risks and the amount of accumulation of $\mathrm{Cd}$ and some ecological important elements in the benthic sediments. These element do not give information only on the human activities as regards ecosystem enrichment, but also the health and ecological risks involved via contacts.

Index of geo-accumulation (I-geo). The values of the I-geo of the selected trace and heavy metals in this study are presented in Table 6 . The mean result values of the I-geo for all the trace and heavy metals ranged from 0.30 to 1.20 , this suggested a possible contamination (Moderately contaminated).

However, the I-geo values were generally low $(<2)$ in all cases. $\mathrm{Cu}, \mathrm{Zn}$, and $\mathrm{Cd}$ contributed to the pollution status of the sediment having I-geo values within 1.00 $-1.20 \mathrm{~g} / \mathrm{Kg}$ (moderately polluted) while the I-geo value of $\mathrm{Pb}$ was too low at $0.30 \mathrm{~g} / \mathrm{Kg}$ which contributed

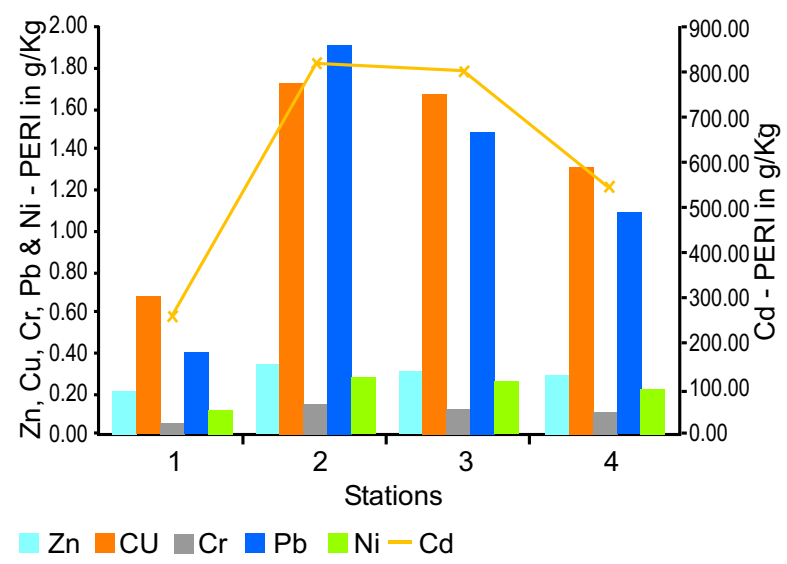

Fig. 5. Spatial distribution of selected trace and heavy metals across the stations indicating Cadmium as the major comprehensive PERI.

Table 5. The results of potential ecological risk index (PERI)

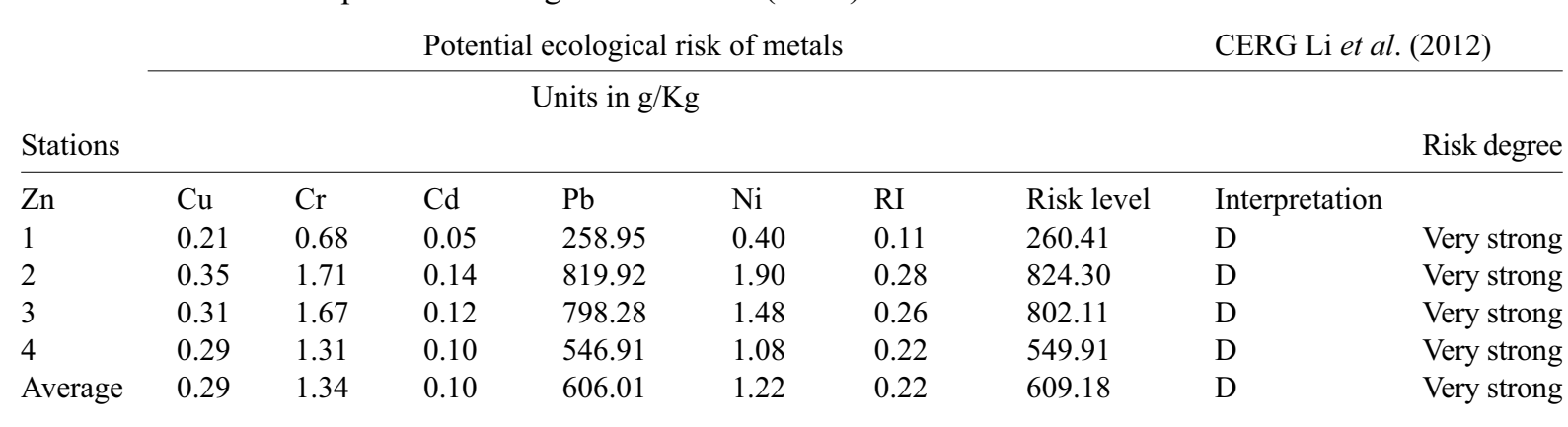

$\mathrm{NB}=$ Comprehensive ecological risk grade (CERG). 
Table 6. The results of index of geo-accumulation (I-geo)

\begin{tabular}{|c|c|c|c|c|c|c|c|c|c|}
\hline \multirow[b]{3}{*}{ Stations } & \multicolumn{5}{|c|}{ Index of geo-accumulation } & \multicolumn{4}{|c|}{ Class of index of geo accumulation Muller, (1981) } \\
\hline & \multirow[b]{2}{*}{$\mathrm{Cu}$} & \multirow[b]{2}{*}{$\mathrm{Zn}$} & \multicolumn{3}{|c|}{ Parameters in $\mathrm{g} / \mathrm{Kg}$} & \multicolumn{4}{|c|}{ Parameters in $\mathrm{g} / \mathrm{Kg}$} \\
\hline & & & $\mathrm{Cd}$ & $\mathrm{Pb}$ & Elements & Mean I-geo & Rank & Class & Interpretation \\
\hline 1 & 0.18 & 0.02 & 0.28 & 0.01 & $\mathrm{Cu}$ & 1.00 & $<2$ & 2 & Moderately polluted \\
\hline 2 & 2.15 & 4.92 & 1.28 & 0.98 & $\mathrm{Zn}$ & 1.20 & $<3$ & 2 & Moderately polluted \\
\hline 3 & 0.39 & 0.02 & 0.97 & 0.01 & $\mathrm{Cd}$ & 1.00 & $<4$ & 2 & Moderately polluted \\
\hline 4 & 0.29 & 0.02 & 0.62 & 0.01 & $\mathrm{~Pb}$ & 0.30 & $<1$ & 1 & Unpolluted \\
\hline Average & 1.00 & 1.20 & 1.00 & 0.30 & & & & & \\
\hline
\end{tabular}

insignificantly to the pollution of the sediment. The identification of the contribution of $\mathrm{Cu}, \mathrm{Zn}$, and $\mathrm{Cd}$ by the I-geo index as the major chemical precursors that contributed to the pollution load of the sediment is an interpretation of the intense agricultural activities and other attendant anthropogenic activities along the stretch of the river. This has also been supported by works of (Naveedullah et al., 2013; and 2014; Shrestha and Kazama, 2007; He et al., 2004; Trocine et al., 1993).

\section{Conclusion}

This current study revealed that all the examined trace and heavy metals exceeded the standard limits as set by WHO and FEPA. A further analysis using one way ANOVA Tukey pairwise test revealed that there was a positive correlation between $\mathrm{Fe}$ with $\mathrm{Zn}, \mathrm{Mn}, \mathrm{Cu}, \mathrm{Pb}$, $\mathrm{Cr}, \mathrm{Cd}, \mathrm{Ni}$ and $\mathrm{V}$. More so, a positive correlation exists between $\mathrm{Mn}$ with $\mathrm{Pb}, \mathrm{Cr}, \mathrm{Cd}$, Ni and $\mathrm{V}$. The values were considered to be less than 0.05 after a statistical computation and were considered significant. A significant difference $(\mathrm{P}<0.05)$ exists between the Krustal-Wallis tests for sample medians.

Eigen values greater than one or equal to one were gotten after the application of the PCA on the sediment parameters showing a collective variance of $101.85 \%$. This clearly indicates that the source apportionment were from anthropogenic influences such as farming. The KMO value obtained was 0.837 , which reveals a better sampling appropriateness. The BTS generated a very significant value of $\mathrm{P}<0.001$, showing that relationship exist between each examined variables.

The study also revealed that the average PERI values ranged from 0.22 to 606.01 . From the risk interpretations, this indicated the metals in the four sampling stations all has very strong ecological risk level with the highest comprehensive PERI values of 824.30 and 802.11 at station 2 and 3 respectively. However, the I-geo values were generally low $(<2)$ in all cases. $\mathrm{Cu}, \mathrm{Zn}$, and $\mathrm{Cd}$ contributed to the pollution status of the sediment having I-geo values within $1.00-1.20$ (moderately polluted) while the I-geo value of $\mathrm{Pb}$ was too low at 0.30 which contributed insignificantly to the pollution of the sediment. The identification of the contribution of $\mathrm{Cu}$, $\mathrm{Zn}$, and $\mathrm{Cd}$ by the I-geo index as the major chemical precursors that contributed to the pollution load of the sediment is an interpretation of the intense agricultural activities and other attendant anthropogenic activities along the stretch of the river. We recommend that the regulatory bodies should reinforce the environmental laws to reduce the impacts of anthropogenic activities in this watercourse.

\section{Acknowledgement}

We appreciate Macgill Engineering and Technical Services Limited (Division of Martlet Environmental Research Laboratory Limited) Benin city, Nigeria for carrying out an analysis laboratory experimental assessment of all samples collected pro Bono within the specific scope of this study with standard quality control and quality assurance measures.

Conflict of Interest. The authors declare no conflict of interest.

\section{References}

Abbasi, S.A., Abbasi, N., Soni, R. 1998. Trace and Heavy Metals in the Environment. 314 pp., Mittal Publications, New Delhi, India.

Adamo, P., Arienzo, M., Imperato, M., Naimo, D., Nardi, G., Stanzione, D. 2005. Distribution and partition of trace and heavy metals in surface and sub-surface sediments of Naples city port. Chemosphere, 61: 800-809.

Addo, M.A., Okley, G.M., Affum, H.A., Acguah, S., Gbadago, J.K., Botwe, B.O. 2011. Water quality 
and level of some trace and heavy metals in water and sediments of Kpeshie Lagoon, La-Accra, Ghana. Research Journal of Environmental Earth Science, 3: 487-497.

Afangideh, A.I., Edet, E.O., Ekanem, E.M. 2008. An analysis of the trend in annual rainfall dynamics for the humid tropics, a case study of Calabar, CRS, Nigeria. Neo-Africanists. Review, 2: 1.

Aktar, M.W., Paramasivam, M., Ganguly, M., Purkait, S., Sengupta, D. 2010. Assessment and occurrence of various trace and heavy metals in surface water of Ganga river around Kolkata: a study for toxicity and ecological impact. Environmental Monitoring Assessment, 160: 207-213. doi://10.1007/s10661008-0688-5.

Al-Taani, A.A., Batayneh, A.T., El-Rasaideh, N., Ghrefat, H., Zumlot, T., Al-Rawabdeh, A.M., Al-Momani, T., Taani, A. 2015. Spatial distribution and pollution assessment of trace metal in surface sediments of Ziqlab reservoir, Jordan. Environmental Monitoring Assessment, 187: 32. doi://10. 1007/s 10661-0154289-9.

APHA, American Public Health Association, 2005. Standard Methods for the Examination of Water and Wastewater. $21^{\text {st }}$ ed. American Public Health Association, Washington DC, USA.

APHA, American Public Health Association (AWWA), (WPCF), American Water Works Association Water Pollution Control Federation 1998. Standard Methods for the Examination of Water and Wastewater. $20^{\text {th }}$ eds., 1325 pp., Washington, DC., USA.

Anani, O.A., Olomukoro, J.O. 2017. The evaluation of trace metal load in benthic sediment using some pollution indices in Ossiomo river, Benin city, Nigeria. Funia Journal of Science and Technology, 3: 103-119. doi://10.13140/RG.2.2.22200.85764.

Anani, O.A., Olomukoro, J.O. 2018. Trace metal residues in a tropical watercourse sediment in Nigeria: Health risk implications. IOP Conference Series: Earth and Environmental Science, 210: 012005.

Anani, O.A. 2017. Heavy metal residues and contamination profiles of water, sediment, Macrobrachium rosenbergii and Sudanonautes africanus in Ossiomo river, Edo state, Nigeria. PhD. Thesis, 212 pp., University of Benin, Benin City, Nigeria.

Bai, J., Cui, B., Chen, B., Zhang, K., Deng, W., Gao, H. 2011. Spatial distribution and ecological risk assessment of trace and heavy metals in surface sediments from a typical plateau lake wetland, China. Ecological Modelling, 222: 301-306.
Balasim, H.M. 2013. Assessment of some heavy metals pollution in water, sediments and Barbus xanthopterus (Heckel, 1843) in Tigris river at Baghdad city. M.Sc Thesis, 159 pp., College of Science, University of Baghdad, Iraq.

Bhardwaj, R., Gupta, A., Garg, J.K. 2017. Evaluation of trace metal contamination using environmetrics and indexing approach for river Yamuna, Delhi stretch, India. Water Science, 45: 15. doi://10.1016/ j.wsj.2017.02.002.

Bhuiyan, M.A.H., Islam, M.A., Dampare, S.B., Parvez, L., Suzuki, S. 2010. Evaluation of hazardous metal pollution in irrigation and drinking water systems in the vicinity of a coal mine area of northwestern Bangladesh. Journal of Hazardous Materials, 179: 1065-1077.

Boszke, L., Sobczynski, T., Kowalski, A. 2004. Distribution of mercury and other trace and heavy metals in bottom sediments of the middle Odra river (Germany/Poland). Polish Journal Environmental Studies, 13: 495-502.

Caeiro, S., Costa, M.H., Ramos, T.B., Fernandes, F., Silveira, N., Coimbra, A., Medeiros, G., Painho, M. 2005. Assessing heavy metal contamination in Sado Estuary sediment: an index analysis approach, Ecological Indicators, 5: 151-169.

Chen, C.W., Kao, C.M., Chen, C.F., Dong, C.D. 2007. Distribution and accumulation of trace and heavy metals in the sediments of Kaohsiung Harbor, Taiwan. Chemosphere, 66: 1431-1440.

Dougherty, C.P., Henricks, H.S., Reinert, J.C., Panyacosit, I., Axelrad, D.A., Woodruff, T.J. 2000. Human exposure to trace and heavy metals consumption from fish. Environmental Research, 84: 170 .

Duce, R.A., Hoffmann, G.L., Zoller, W.H. 1975. Atmospheric trace metals at remote northern and southern Hemisphere sites. Pollution or Natural Science, 187: 59-61.

Enuneku, A.A., Mohammed, O.P., Asemota, O.C., Anani, O.A. 2018. Evaluation of health risk concerns of trace metals in borehole water proximal to dumpsites in Benin city, Nigeria. Journal of Applied Science and Environmental Management, 22: 1421-1425. DOI: doi://10.4314/jasem.v22i9.10.

Essien, J.P., Antai, S.P., Benson, N.U. 2006. Microbial population dynamics as a function of sediment salinity gradients in the Qua Iboe Estuary Mangrove Swamp (Nigeria), Research Journal of Microbiology, 1: 255-265. 
FEPA (Federal Environmental Protection Agency). 2003. Guidelines and standards for environmental pollution control in Nigeria. Federal Environmental Protection Agency, 238 pp.

Grimm, L.G., Yarnold, P.R. 2000. Introduction to Multivariate Statistics. In: Reading and Understanding More Multivariate Statistics, L. G. Grimm and P.R. Yarnold (eds.), pp. 3-21. American Psychological Association, Washington, USA.

Hakanson, L. 1980. An ecological risk index for aquatic pollution control. A sedimentological approach. Water Reports, 4: 975-1001.

He, Z., Zhang, M., Calvert, D., Stoffella, P., Yang, X., $\mathrm{Yu}, \mathrm{S}$. 2004. Transport of trace and heavy metals in surface runoff from vegetable and citrus fields. Soil Science Society of America Journal, 68: 1662.

ITRC (Interstate Technology and Regulatory Council). 2016. Geospatial Analysis for Optimization at Environmental Sites (GRO-1). Washington, DC: Interstate Technology and Regulatory Geostatistics for Remediation Optimization Team. www.itrcweb. org/gro-1.

Jain, C.K., Sharma, M.K. 2006. Trace metal transport in the Hindon river basin, India. Environment Monitoring Assessment, 112: 255-270.

Krivoruchko, K. 2011. Spatial Statistical Analysis for GIS Users, 928 pp., Esri Press, Redlands, California, USA.

Li, R.Z., Pan, C.R., Xu, J.J., Ding, G.Z., Zou, Y. 2012. Application of potential ecological risk assessment model based on monte carlo simulation. Research Environmental Science, 25: 1336-1343.

Manoj, K., Padhy, P.K. 2014. Distribution, enrichment and ecological risk assessment of six elements in bed sediments of a tropical river, Chottanagpur Plateau: A spatial and temporal appraisal. Journal of Environmental Protection, 5: 1419-1434. doi://10. 4236/jep.2014.514136

Martin, J., Meybeck, M. 1979. Elemental mass-balance of material carried by major World rivers. Marine Chemistry, 7: 173-206.

Muller, G. 1981. Die Schwermetallbelstung der sedimente des Neckars und seiner Nebenflusse: eine estandsaufnahme. Chemistry Zeitung, 105: 157-164.

Muller, G. 1969. Index of geo-accumulation in sediments of the Rhine river. Geology Journal, 2: 108-118.

Nair, I.V., Singh, K., Arumugam, M., Gangadhar, K., Clarson, D. 2010. Trace metal quality of Meenachil river at Kottayam, Kerala (India) by principal component analysis. World Applied. Science Journal, 9: 1100-1107.

Naveedullah, Hashmi, M.Z., Yu, C., Shen, H., Duan, D., Shen, C., Chen, Y. 2014. Concentrations and human health risk assessment of selected trace and heavy metals in surface water of the Siling reservoir watershed in Zhejiang province, China. Polish Journal of Environmental Studies, 23: 801811.

Naveedullah, Hashmi, M.Z., Yu, C., Shen, H., Duan, D., Shen, C., Chen, Y. 2013. Risk assessment of trace and heavy metals pollution in agricultural soils of siling reservoir watershed in Zhejiang Province, China. Hindawi Publishing Corporation BioMed Research International, 10: doi://10.1155/ 2013/590306.

Nummelin, M., Lodenius, M., Tulisalo, E., Hirvonen, H., Alanko, T. 2007. Predatory insects as bioindicators of heavy metal pollution. Environmental Pollution, 145: 339-347.

Odoemelam, S.A., Okorie, D.O., Oko, I.O. 2013. Physico-chemical parameters and trace metal content of water, fish and sediments from cross river at Afikpo north local Government area of Ebonyi state, Nigeria. Bioresources Bulletine, 010015.

Oliver, M.A., Webster, R. 1990. Kriging: a method of interpolation for geographical information system. Geological Information System, 4: 313-332.

Opaluwa, O.D., Aremu, M.O., Ogbo, L.O., Odiba, I.E., Ekpo, E.R. 2012. Assessment of trace and heavy metals in water, fish and sediments from Uke Stream, Nasarawa state, Nigeria. Current World Environment, 7: 213-220.

Prasad, B., Kumari, S. 2008. Trace metal pollution index of ground water of an abandoned open cast mine filled with fly ash: a case study. Mine Water Environment, 27: 265-267.

Prasad, M.B.K., Ramanathan, A.L., Shrivastav, S.K., Anshumali, R.S. 2006. Metal fractionation studies in surfacial and core sediments in the Achankovil river basin in India. Environmental Monitoring Assessment, 121: 77-102.

Radojevic, M., Bashkin, V.N. 1999. Practical Environmental Analysis. Royal School of Chemistry, 645 pp., Thomas Graham House, Science Park Cambridge, UK.

Reimann, C., de Caritat, P. 2005. Distinguishing between natural and anthropogenic sources of element in the environment: regional geochemical surveys 
versus enrichment factors. Science of the Total Environment, 337: 91-107. doi://10.1016/j.scitotenv. 2004.06.011.

Reza, R., Singh, G. 2010. Trace metal contamination and its indexing approach for river water. International Journal Environment Science Technological, 7: 785-792.

Shrestha, S., Kazama, F. 2007. Assessment of surface water quality using multivariate statistical techniques: A case study of the Fuji river basin, Japan. Environmental Modelling Software, 22: 464-475.

Sundaray, S.K. 2009. Application of multivariate statistical techniques in hydro-geochemical studies-a case study: Brahmani-Koel river (India). Envi-ronmental Monitoring Assessment, 164: 297-310.

Talarico, F., Brandmayr, P., Giulianini, P.G. 2014. Effects of metal pollution on survival and physiological responses in Carabus (Chaetocarabus) lefebvrei, (Coleoptera, Carabidae), European Journal of Soil Biology, 61: 80-89.

Tao, S. 1995. Kriging and mapping of copper, lead, and mercury contents in surface soil in Shenzhen area. Water, Air and Soil Pollution, 83: 161- 172.

Tepanosyan, G., Sahakyan, L., Kafyan, M., Saghatelyan, A. 2017. Geospatial mapping, source identification and human health risk assessment of trace and heavy metals in soils of Gyumri (Armenia). $15^{\text {th }}$ International Conference on Environmental Science and Technology Rhodes, Greece, 31 August to 2 September. CEST2017_00489.

Trocine, R.P., Trefry, J.H., Windsor, J.G., Surma, J.M. 1993. Toxic substances survey for the Indian river Lagoon system. Florida Institute of Technology.
Marine and Environmental Chemistry Laboratories.

Turekian, K.K., Wedepohl, K.H. 1961. Distribution of the elements in some major units of the earth's crust. Geological Society and America Bulletin, 72: 175-192.

Ugwu, A.I., Wakawa, R.J., La'ah, E., Olotu, A. 2012. Spatial distribution of trace and heavy metals sediments and study of factors impacting the concentration in river Usuma. IJRRAS, 12: 294-303.

Wang, X.J., Zheng, Y., Liu, R.M., Li, B.G., Cao, J., Tao, S. 2003. Kriging and PAH pollution assessment in the topsoil of Tianjin area. Bulletin of Environmental Contamination and Toxicology, 71: 189-195.

Webster, R., Oliver, M. 2007. Geostatistics for Environmental Scientists. $2^{\text {nd }}$ edition, 330 pp., John Wiley and Sons, Ltd., Chichester, South East, England, UK.

Wei, B.G., Jiang, F.Q., Li, X.M., Mu, S.Y. 2010. Trace metal-induced ecological risk in the city of urumqi, NW China. Environmental Monitoring Assessment, 160: 33-45. http://dx.doi.org/10.1007/ s10661-0080655-1.

WHO (World Health Organization), 2003. Chromium, zinc, lead, in drinking-water. Background.

Yalcin, M.G., Tumuklu, A., Sonmez, M., Erdag, D.S. 2010. Application of multivariate statistical approach to identify 'trace metal sources in bottom soil of the Seyhan river (Adana), Turkey. Environmental Monitoring Assessment, 164: 311-322.

Yisa, J., Jacob, J.O., Onoyima, C.C. 2012. Assessment of toxic levels of some trace and heavy metals in road deposited sediments in Suleja, Nigeria. American Journal of Chemistry, 2: 34-37.doi:// 10.5923/j.chemistry.20120202.08. 